\title{
Art and Artist Movement in Banten Edi Bonetski X PengPeng
}

\author{
Gisela Anindita
}

New Media Program, School of Design, BINUS University

E-mail: gisellaaninditaa@gmail.com/gisela.putri@binus.ac.id

\begin{abstract}
Banten is one of the provinces in Indonesia. It is located in the westernmost of Java. Art Movement in Banten is not as famous as Jakarta, Yogyakarta, nor Bali. Being an Artist is not the most famous, not even an option for Banten's job or career. Being an artist in Banten is because the people are not familiar with the art, especially contemporary art. So being an artist in Banten means also being an educator for social change. Edi Bonetski and PengPeng, both are Banten born and raised artist, are trying to make an art movement in Banten. They are doing what I called "terror" in the two cities of Banten. Serang and Tangerang, through their artistic collaboration. The aim is to habituate people in Banten for seeing art. The more they make, the more people will get used to appreciate and live with art. They also made their artistic collaboration in the crowd area, so people can watch how art makes. This "terror" might be something common in Jakarta or Yogyakarta, but not in Banten. They change people's minds about art through their process demo and collaborate with anybody in the process. This practice is to engage people to learn art by doing an art activity.
\end{abstract}

Keywords: art movement, banten, social change, artist

Pergerakan Seni dan Seniman di Banten Studi Kasus: Edi Bonetski X PengPeng ABSTRAK

Banten adalah salah satu provinsi di Indonesia ysng terletak di paling barat Pulau Jawa. Gerakan Seni Rupa di Banten memang tidak terlalu terkenal dibanding Jakarta, Yogyakarta, atau Bali. Menjadi seniman bukanlah yang populerl, bahkan tidak menjadi pilihan pekerjaan atau karir di Banten. Perjuangan menjadi seniman di Banten disebabkan oleh masyarakat yang belum mengenal seni khususnya seni kontemporer. Menjadi seniman di Banten berarti juga sekaligus menjadi pendidik untuk perubahan sosial. Edi Bonetski dan PengPeng, merupakan dua seniman yang lahir dan besar di Banten, yang mencoba membuat gerakan seni di Banten. Mereka melakukan apa yang saya sebut dengan "teror" di dua kota Banten. Yakni Serang dan Tangerang, melalui kolaborasi seni mereka. Tujuannya adalah untuk membiasakan masyarakat Banten untuk melihat kesenian. Semakin banyak mereka membuat, semakin banyak orang yang terbiasa untuk mengapresiasi dan hidup dengan seni. Mereka juga berkolaborasi di area keramaian, sehingga masyarakat bisa menyaksikan bagaimana proses pembuatannya. "Teror" ini mungkin sudah biasa di Jakarta atau Yogyakarta, tapi tidak di Banten. Bagaimana mereka mengubah pikiran orang tentang seni melalui demo proses mereka, dan kolaborasi dengan siapa pun dalam prosesnya. Latihan ini mengajak masyarakat untuk belajar seni dengan melakukan aktivitas seni.

Kata Kunci: gerakan seni, banten, perubahan sosial, seniman 


\section{INTRODUCTION}

Howard Becker classified artist into four categories. One of the categories is High Street Artist born and raised their art reputation not through a gallery, but from any other artist. Most High Street Artists might have a lower price than Emerging Artist, but their reputation is equal. Edi Bonetski was categorized as High Street Artist based on his characteristic. He started his art activity since he was a teenager as a musician. He was born and raised in Tangerang City, Banten. As the record, Banten has a relatively small number of artists, compared to another Province in Indonesia.

Edi Bonetski's movement itself was started in the neighborhood where he lives. In a neighborhood community called Karang Taruna (youth group), he teaches art through activities and managed the youth to make social activities, like collecting the garbage and recycle it into a musical instrument and fashion show with clothes made from used goods. In 2003, Edi founded Rumah Belajar Anak Langit at Cisadane River's side, a school for street children. They teach lessons in formal school through art. After Sanggar Anak Langit being evicted by the government, Edi and his partner build an art center in Tangerang, named SEMANGGI (Semangat Berbagi/Spirit of Sharing). Now, SEMANGGI is a home for street artists, newcomer artists, or anyone who wants to learn and share art. Edi himself becoming a father of the youth and street artist in Banten. Recently, Edi making music, performances art, and painting as his art activity and movement.

Sebastianus Advent, known as PengPeng, was born and raised in Serang, the capital city of Banten. He started his art activity at Sanggar Embun, an art community in Serang. He comes up as a photographer. His main concern is about humans as the center of cultural transformation and humans as itself. He graduated from Institut Seni Indonesia Yogyakarta and returned to Serang to create a new atmosphere for art, artist, and society in his hometown. He wants to re-build a spirit of art in Serang through art activity. Recently, he learns and experiments with printmaking as a method for presenting his art. In Banten, printmaking is not a standard art method; therefore, he wants to educate and introduce artists and people in Banten to any other art method besides painting, photography, and sculpt.

Edi Bonetski and PengPeng have the same spirit of educating people through art. In 2020, during the pandemic, they decide to have an art activity collaboration. They made three artworks in 3 different public spaces. Their collaboration aims to release their creativity during lockdown and engage any other artist, especially in Banten, to keep being productive during the pandemic. PengPeng uses his face-up method to present his collage artwork about human and television influence into $2 \times 1,5 \mathrm{~m}$. Edi responds to PengPeng artwork with an impressive sketch painting above PengPeng's face up. Their collaboration artworks 
IJCAS | Volume 7 Number 2, December 2020

p-ISSN 2339-191X | e-ISSN 2406-9760

have a "terrorizing" impression for the viewer because, in Serang, this is the first art that used face-up as a method. The gigantic size of the human picture also builds up the "terrorizing" impression.

While in Banten, especially in Serang, the familiar artworks are painting, photograph, and sculpture about local culture, Edi and PengPeng propose a whole new art method and issue in Serang. This is a challenge to break an old art culture in Serang and the culture of Serang City social itself.

\section{MATERIALS AND METHOD}

In my research about High Street Artist, I focus on what they are doing. I following Edi and PengPeng for a couple of months to observe how they involve in their society. Their social is quite different compare to Emerging/Superstar Artist. They mostly have friendships with the marginalized such as street children, street punk, street performer, etc. Those particular things that make a difference for High Street Artist, besides living as an artist, are also an educator for their surroundings because they choose and have the privilege to living and giving their knowledge for the society.

As long as I research, this characteristic of High Street Artist would not be found in any other artist categories based on Howard S. Becker. I choose Edi and PengPeng for a reason. They both lived in Banten, and they were already struggling to educate, persuade, and at once making artwork. It is seen by how they produce their artwork by always being close to society. They use a material that anyone can obtain every day; they do not always use the same material in each artwork. They select public space as their presentation. They research their content issue and then visualized it into their artwork. In making artwork, they are always surrounded by people who passers-by in the public space or street.

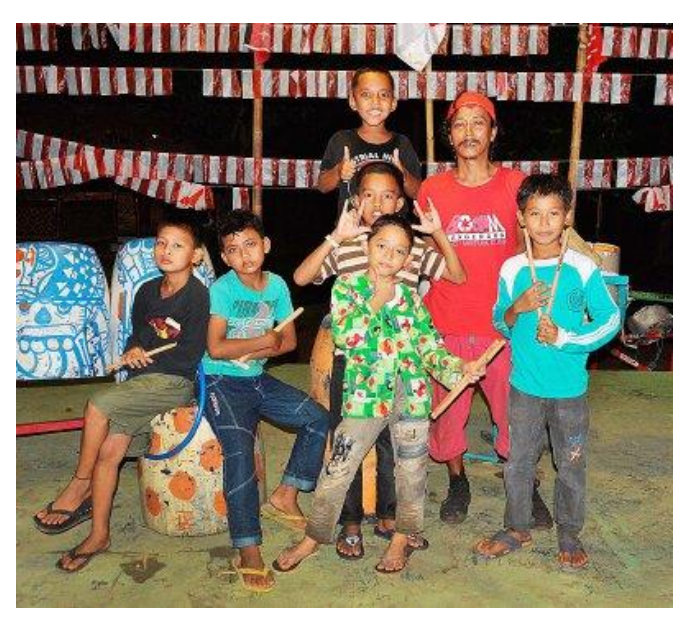

Figure 1. Edi with Sanggar Anak Langit Source: https://kompasiana.com/



Figure 2. Edi with Sanggar Anak Langit Source: Gisela Anindita's Documentation, 2020 


\section{RESULTS}

\section{HIGH STREET ARTIST Movement}

as Community Educator

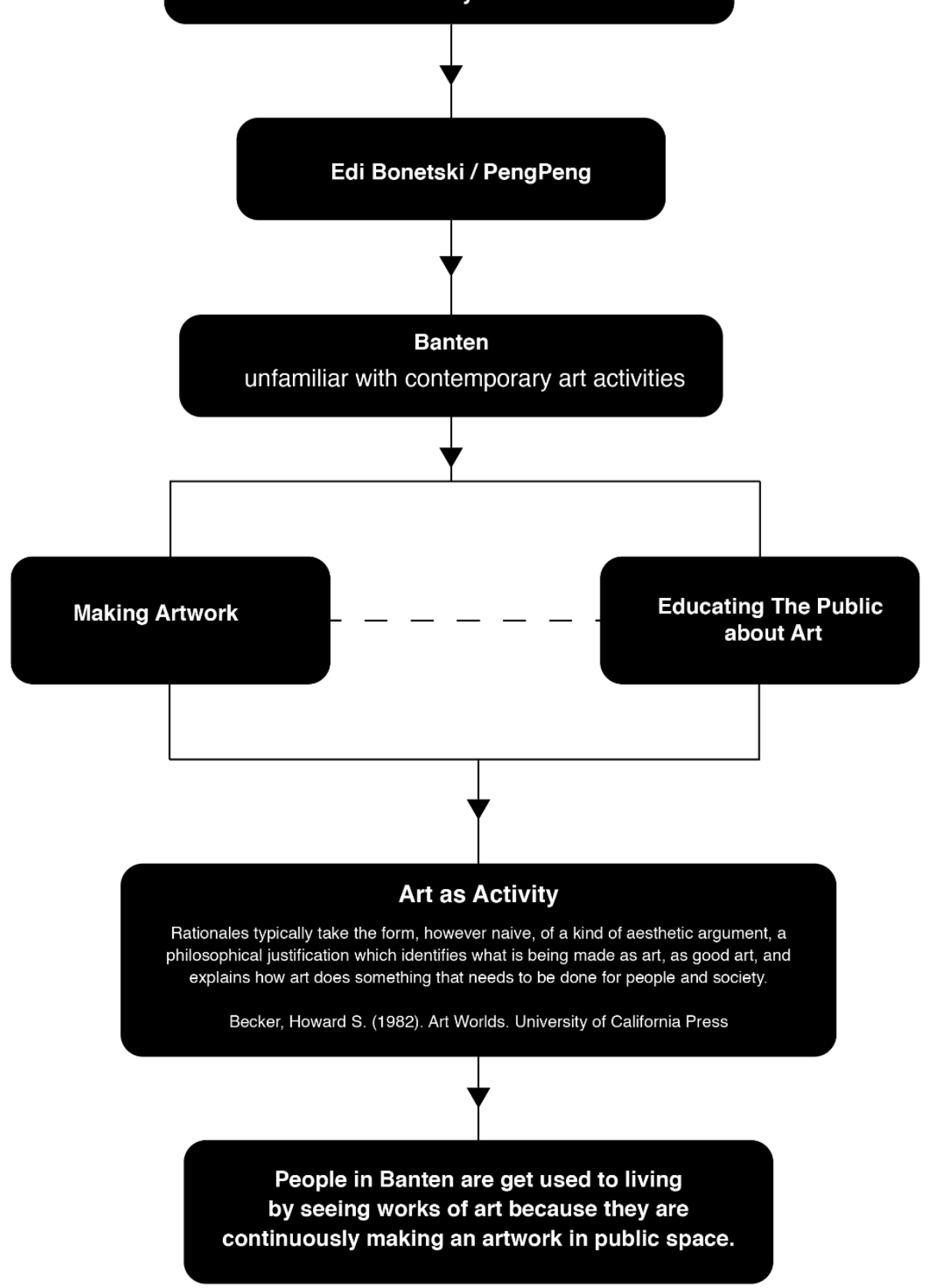

Table 1. High Street Artist Movement

Source: Gisela Anindita's Documentation, 2020 
IJCAS | Volume 7 Number 2, December 2020

p-ISSN 2339-191X | e-ISSN 2406-9760

Departs from High Street Artist theory, I focus on their role as a community educator. Edi Bonetski and PengPeng movement in Banten, the province that unfamiliar with contemporary art activities. Edi and PengPeng have two different roles as artists, making artwork and educating the public about art. They both doing those two roles in one activity. They involved the community in making artwork while the community is learning about the art. When they do art activities continuously, the community will get used to seeing, living, and appreciating art in their daily aesthetic.

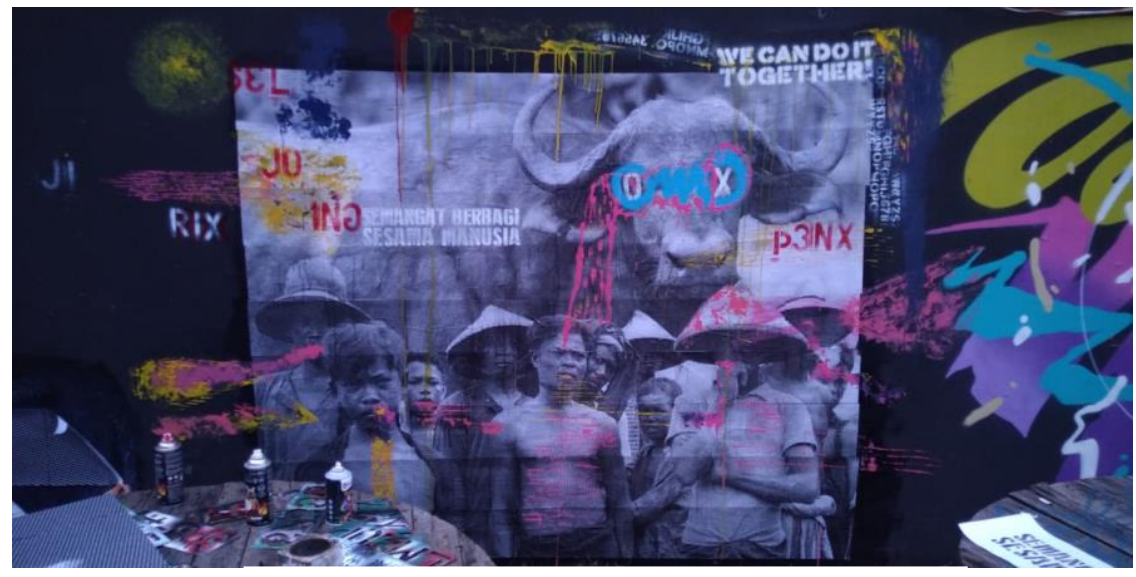

Figure 3. Edi and PengPeng Artwork (1)

Source: Gisela Anindita's Documentation, 2020

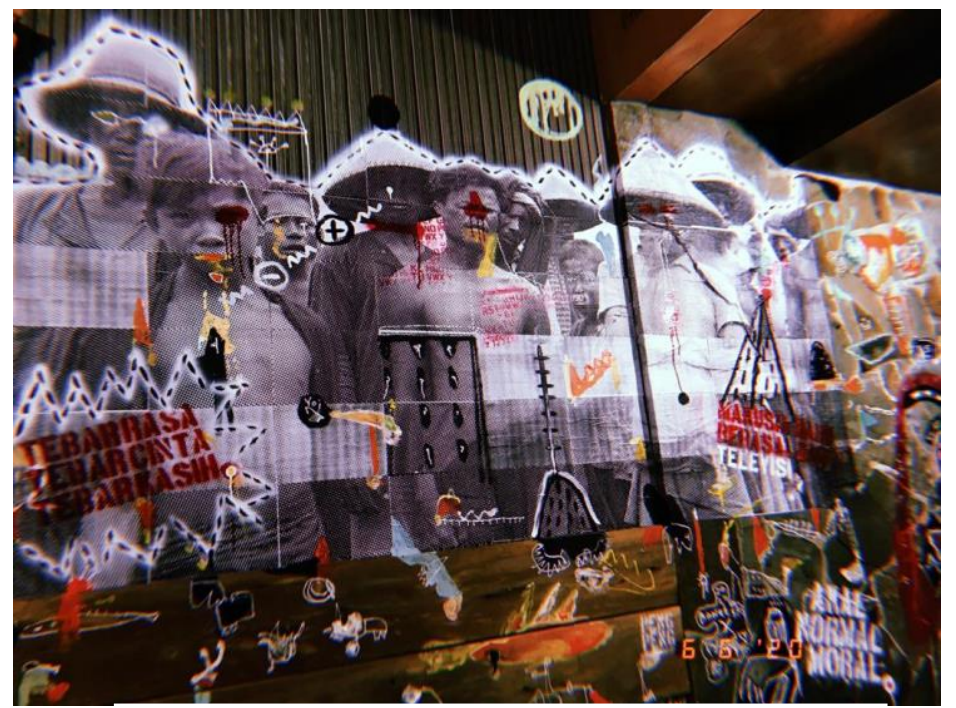

Figure 4. Edi and PengPeng Artwork (2) Source: Gisela Anindita's Documentation, 2020 


\section{DISCUSSION}

The activities carried out by the two artists are literal practices from Howard S. Becker's theory of art activity and collectivism. There are some points to do an art activity, such as continuity to educating people on how to see art. Through continuous artistic activity, people will exercise and become familiar with the art, then add to their aesthetic experience. Continuity is only possible if there is stability. Becker's mean about stability is about providing space for an art activity, legal law, and support from society and government (Becker, 1982).

Secondly, recently, not so many artists are committed to educating. Social problems are just exploitable content for the artwork. If social problems are resolved, then it seems as if there is nothing left to exploit in works of art. Accordingly, art as an activity is one of the most challenging jobs to committed. The artist should get close to social problems without exploiting them.

\section{CONCLUSION}

High Street Artist have a different context with others artist categories. They do their art activity based on social and friendship. Their success indicators are not galleries, collectors, or high artwork price. They have a different definition of success. For them, successful art means being beneficial to the surrounding. Art can be delivered through anything. One example that is done most often is through children's education.

However, like any category of artists, consistency is a must-have. People need consistency to change. Furthermore, as educators, the artist needs to doing art activities continuously. In the beginning, they might say a movement for their work. However, after they are doing it continuously, it becomes an art activity that happened every day and their ordinary activities. Educating is no longer looked like something heavy, but it has already become part of the daily life activities. In Banten, a province that unfamiliar with contemporary art, this is a challenge for this movement. However, that will bring forth any other movement from High Street Artist. Edi and PengPeng are one among many High Street Artist in Banten that starting the movement.

\section{REFERENCES}

Becker, H. S. (1982). Art Worlds. United State: University of California Press.

Bruno Fredrik Resch, M. (2011). Management of Art Galleries - Business Model. University of St. Gallen.

Sunardi, S. (2016). Pertukaran Nilai-Nilai Dalam Pasar Seni Sebuah Sketsa Awal. Retorik| Jurnal Ilmu Humaniora, 4(2). 
IJCAS | Volume 7 Number 2, December 2020

p-ISSN 2339-191X | e-ISSN 2406-9760

Zolberg, V. . (1990). Constructing a Sociology of The Arts. https://doi.org/https://doi.org/10.1017/CBO9780511557712

Interview with Edi Bonetski and PengPeng (2020). 